\title{
1987年度大会特別研究発表
}

——報告・討論の要旨および座長の所見——

岡橋秀典 : 山村空間の周辺化と地域的再編成

藤田 佳久

（1）報告の内容 発表者の関心は，山村の状況変 化に応じて推移し, 最初は山村を変容させる経済的 ファクターを主に労働市場の面から考察してきたが， 最近では山村内部の社会構造へと関心が移ってきた とする。今回の発表はこの 2 つの内容を合体させた もので, 題目の「山村空間」の用語は, 外部ファク ターによって編成された周辺地域としての山村を， 「地域的再編成」の用語は, 山村内部の自立的再編 成，をそれぞれ含意して用いているとした。

総体としての山村空間は, 世界, ナショナル （国），地域（地方）の3つのスケールでの周辺化を 重層的に受けているとし，第一に，日本の山村は 「世界の中心地域の中の周辺地域」（Skeldon，1985） として位置づけられ，そこでは伝統的牧畜の衰退や リクリエーション地域化が進行するが，このような 現象は山村の自然条件だけではとらえられないこと， 第二に，日本市場の狭さから戦前には多分に自給的 性格を残していた日本山村は, 戦後の社会経済的諸 現象に伴い，まず人口の急激な減少による過疎化， 次いで山村に居住しつつ製造業や建設業へ就業する 経済・労働市場再編，そして低成長期以降就業機会 や村おこしの頭打ちと年金給付や退職者移入の増加 という周辺化を受けていること, 第三に, 山村はコ ア（中心）をなす大都市の日本の中での位置づけや 各山地ごとの隔絶性・分断性・土地条件に規定され た周辺化を受けていることとし，山村空間をこのよ うに整理することができるとした。

次に, 山村の地域性に関して検討し, 林野率 $80 \%$ 以上でD I Dをもたない683の行政市町村を山村と みなした上で，30以上の変数に関する主成分分析に より8成分を抽出し, さらに社会経済的成分と解釈 される上位 4 成分によるクラスター分析を行い， 6 タイプの山村に分類した (発表要旨第 2 図)。第 1 類型は平均的状態, 第 2 類型は雇傭面の改善と高齢 化の状態, 第 3 類型は高齢化は進んでいないが雇傭
面の悪い状態，第 4 類型は商齢化が進み雇傭面の状 態も悪い最も深刻な状態, 第 5 類型は第 6 類型に準 ずる状態，第 6 類型は非過疎的な状態を示す，とい うことができるとする。この図から, 従来言われて いた東西日本の対照性が全国山村での平準化とミク ロレベルでの過疎の深刻化などにより不明瞭・分散 化していることがわかったとし，また，大都市を中 心とした同心円的地帯構成，大都市圈・中間地域 · 周辺地域の経済格差構造の山村への反映なども考慮 し, さらに既往の研究成果もふまえて全国の山村を 8つの地域類型に分けることができるとした。

以上の, 山村の周辺化や地域性に関する検討を踏 まえ, 次に, 現実の山村の自立的な地域的再編成に ついてふれた。この場合, 社会システム・社会組織 ・社会集団を基礎にした地域的再編成の考察が不可 欠であるとし, とりわけ, 山村内部の, (1)既存の村 落社会システムの再編成, (2)上り上位の自治体や農 協によるシステム化，(3)山村の外部（都市）にある 第二の村というべき同郷団体との結合に注目し，そ れぞれ事例を示しつつ検討を行った。

(1)では, 村落社会を, 土地・経済・社会及びこれ ら 3 者を結びつける主体系の計 4 つのセクターから なるシステムとして捉えると, 前 3 セクターがかな り村落内部で完結しており, かつ主体系セクターが 広域レベルの施策との対応を計りながら 3 つのセク ターの活性化にも成功している例として新潟県入広 瀬村大白川新田を示した。そこでは土地セクターで は旧入会林野を生産森林組合経営にして村内部での 総有性・平等性を保証していること, 社会セクター では「地主小作制＋同族集団」の衰退と地縁性の拡 大がみられること, 経済セクターでは村落内部での 豊富な就業機会を図っていること, 主体系セクター では地主的リーダーから実務的リーダーへと主導権 が移り補助金獲得や伝統文化継承を進めていること などの実態を紹介, (2)農協・自治体を基礎とした地 域的再編成の事例として大分県大山町をとりあげ, マネジメント機能が一元化され, 早くから米以外の 
少量多品目の地場市場への出荷や固定資本のきりつ めと各農家に即した産地化の配慮を行なってきたこ と,これらを部落横断的に進める一方で新規のコミ ュニティを組織し，また今後の人材育成のため海外 研修制度も採用していることを紹介した。(3)都市の 同郷団体の地域的再編成機能については，役場等へ のアンケート調査結果から, 一般に, 中国・四国で は自然発生的で設立年次の古い同郷団体が多く, 離 村者の都市での求職機会に過疎以前から機能してい たこと, 一方東北では, 成立が遅いものの, 近年の 村㧍こし運動を背景に母村行政機関が同郷団体を出 先機関化する傾向が強いこと, 同郷団体の会員は, 出身村とのつながりを 6 割が維持し, 帰属意識や帰 村希望も強く, 離村者にとって母村として重要なつ アクターをいまだに持っていること,さらに物産販 売などで経済的に同郷団体が関わる例もあることな どから同郷団体が山村の地域的再編成に果たす役割 は，今後一層重要性を増すと考えられるとした。そ してさらに広島県加計町出身者のアンケート調査か ら，広島市との結合性の強さを紹介した。

\section{（2）討論〔菻口善美(駒沢大)〕 (1)「周辺化」の} 言葉を説明してほしい。概念規定が多義的である。 後の方では過疎の話かとも感じた。「周辺性からの 脱却」は「後進性からの脱却」とどう異なるのか。 全般に「周辺化」は「中心からの影響によって生じ た変化」の意味に解せたが，それではいけないのか。 ただその場合，「周辺性からの脱却」の意味がわか らなくなる。(2)ナショナルスケールの話を裏づける ようにケーススタディ(ミクロスタディ) が用いら れる。しかし，そのケーススタディは，悉皆調査に 適した対象域の規模であるにもかかわらず，住民・ 世帯数・人口などの分析によって現象発見するもの で, 真のケーススタディとは言えない。本発表はひ とつのパースペクティブの提示にすぎないのではな いか。(3)「システムの統合」とはどういうことか, 不明である。

〔岡橋〕 (1)「周辺化」の言葉は第三世界論での用法

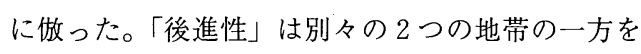
指すときの用語である。「僻地」「辺地」の語も，お かれた地点の悪さに由来する語である。これらとは 異なり, 中心によって統合された中での後進の状態
であることを強調する語として「周辺化」を用いた。 「過疎化」というよりは「周辺化」の方が構造的な 概念である。また「変化」や「変容」の語は, よく 用いられるものの，その主体が不明なままになるの で用いない。

[溝口常俊(富山大)] 菉口先生の質問と関連がある が, 発表では，世界・全国・地方（ミクロ）の 3 地 域スケールすべてで，同じコアとペリフェリー（周 辺化）という言葉を使っている。3スケールでの 「周辺化」を同じものと考えているのか，あるいは 違うものと考えているのか。違うというならどのよ うに違うのか。

〔岡橋〕 3 スケールの「周辺化」はそれぞれ違うと 思う。ミクロスケールの都市山村関係は，その都市 の全国スケールでの機能に対応して規定されており， 二重の周辺化として現れる。私はこれを四国の山村 なら全国スケールの周辺の中の周辺, 一方では国ス ケールのコアの周辺というふうに捉えた。質問への 十分な答えにはなっていないと思うが，さらに考え ていきたい。

〔高野岳彦(東北大)〕 (1)発表者は同郷団体が山村の 地域的再編成に一定の役割を果たしているというが, 単に親睦団体にすぎないのではないか。それとも， 同郷団体が山村生産物の都市への流通チャンネルと して機能したり，都市での収入を山村に送金して山 村再建に役だてているなどの事実があるのか。(2)発 表要旨第 2 図の山村類型に扔いて, 東北地方では平 均的な山村 ( I 類型) が卓越し, 沿岸部に四類型が 多くなっている。しかし, 東北地方の山村は面積が 大きいため, 1 行政市町村内での変異の著しい点が 小規模な西日本の山村と基本的に異なる。そのため, 行政町村を統計単位とするとその変異が相殺され, 平均的な I 類型となってしまう。また沿岸部の正類 型の村は山村でなく漁村と思われる。

[岡橋〕 (1)さまざまのタイプの同郷団体がある。戦 前からの同郷団体の中には強い力（呼び寄せ, 就職, 同化の機能など）をもつものも数は少ないが存在す る。東北出身者の団体はふるさと会員を集める空口 として大きな機能をもっている。親睦が中心なのは 事実だが，会則に「郷土の発展」を盛り込んだり， 自らを山村の純人口と称したり, 山村振興のための 
提言をしたり，寄付をしたりする例もあり，それら を積極的に評価したい。(2)作業過程で自分もそのよ うに思ったが, 旧村スケールでのデー夕収集が困難 （特に国勢調査）なためこうせざるを得なかった。 漁村との指摘に対しては，林野率 $80 \%$ 以上でD I D をもたないの 2 点を基準に山村を定義したのでこう なった。北海道なども含め, さらに検討の余地があ ると思う。

[平岡昭利(鹿児島女子短大)] (1)私は同郷団体が山 村の地域的再編成機能を強くもつと考える。宅配の ふるさと便は同郷団体をチャネルにしている。定年 州村時の発言力や地位確保のためにも同郷団体会員 は郷里の山村への注意を点たらない。(2)母村が強い 共同体結合を有した場合, 都市の同拫団体もその性 格を継承すると考えられないだろうか。

〔岡橋〕 (1)帰村を考えている者は郷里の情報を常に 集めているし，同郷団体がその情報収集の場になっ ていることも多い。(2)共同体と同郷団体とは性格が 異なるものが多い。都市でのマイノリティ性が高い 沖縄などの同郷団体は, 広島・四国などの同郷団体 と比べてきわめて高い機能をもち, 頻繁な日常活動 を行なっている。

[坂元賢次(岡山大学・院)] (1)過疎化の一因に商品 生産の展開の崩壊があったと思う。発表者は山村を 自給的であったとするが，自給的性格は強くなかっ たのではないか。(2)周辺化との関連で, 村落構造の 再編成には経済的基盤が重要であろう。大山町の事 例で重要性を指摘しながらも, 発表者は最終的には 経済的基盤をあまり重視していないと思える。

〔岡橋〕(1)西日本の山村ではたしかに商品生産が展 開していた。たた，戦前の商品生産と戦後の商品生 産とに構造的な相違がある点を重視したい。(2)継続 的な公共投資は今日では財政上望めない。また経済 的基盤の確立には社会構造の变革が前提として必要 だが，それの期待できない山村も多い。山村の数も 多く社会変革も困難な以上, 山村の分化はさらに進 むだろうが仕方がないと思う。このような見通しを 述べたのであって，評価を述べたのではない。

（3）座長所見 岡橋氏の発表は, 近年の山村を位 置だけでなく, 機能的にも周辺地域, さらに「周辺 化」としてとらえ，これまで自らの研究の中心とな
っていた労働力市場分析をべースに，新たに社会組 織の観点を加えて，山村の動きを統一的に理解しよ うとしたところにユニークさがあった。また「周辺 化」の概念化を試み, それを鍵概念としてそれを解 こうとしたところに問題へのアプローチの構想がう かがわれ，意欲的な発表であったと思われる。

それゆえ，それらの基本概念に対するいくつかの 質疑があったのは当然のことでもあった。それらの 質疑を拝聴しながら, あらためて「山村」とは何か を自ら問う気持になったのは恐らく筆者だけではあ るまい。それは岡橋氏の立論の中に,「山村」=「周 辺化」の前提がかなりはっきりと組み込まれていた ことによるためであろう。それゆえ，むしろ，「山 村」そのものにとらわれず,「周辺化地域論」とで もいうべき論理を正面にかかげて立論した方が, 地 域論としてはより一般化への展開を容易にするので はないかと思われた。「山村」にこだわったため, また，山村設定が市町村単位と便宜的であったため， 市町村規模のもつ地域差が質疑されることにもなっ たといえる。

それはまた，岡橋氏が主成分分析と大都市を中心 とした地帯構成から, 山村の 8 地域類型を設定した さい，前者による区分はともかく，地帯構成におけ

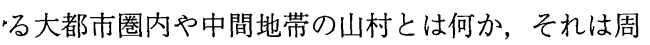
辺地帯の山村とはどう異なるのか, そしてそれぞれ が「周辺化」とどのようにかかわるのか, といった 点が明白でなく，ここでもあらためて「山村」の概 念がかかわらざるをえないことにもなるからである。

なお,この山村類型についていえば, 後述の $3 つ$ の地域的再編成の事例との関係がもう一つはっきり しなかったように思われる。これらの 3 つの事例そ れぞれは興味深いものであるが, それぞれが地域類 型をふまえて抽出されたものなのか，それとは全く 別個の偶然的なものなのか, さらにまた，類型化と の関係で一般化が可能なものなのか, その整合性が はっきりしなかったために，立論との関係が十分生 かしきれなかったように思われる。もし, 明確な整 合性がある場合には, 都市の同郷団体という興味深 い事例の意味づけもさらにはっきりすることになっ たであろう。

ところで, 最後に, 自立的再編成をとげつつある 
として紹介された 3 つの事例山村は，それがその通 りであるならば，メインテーマの「周辺化」概念の 内容と矛盾することにならないのかといった問題が 残る。それはテーマ自体の「周辺化」と「地域的再 編成」の両概念の論理としての整合性と因果関係を 問うことにもなろう。レジュメではそれを地域分化 の事例として説明しているが，そうであるならば, 自立的再編成もまた周辺化の宿命枠から脱しきれな いメカニズムも示した方がよかったように思われる。

なお, 事例としては, むしろ, 岡橋氏のいうとこ ろの世界，国，地域といった多様なスケールの重層 化した「周辺化」の実態を，そのような観点から解 きほぐして示してもらえたら，立論がさらにシャー プになったようにも思われるが，いかがなものであ ろうか。

以上，拝聴者の一人として思うところを述べさせ ていただた。色々思う所が多かっただけ，発表内 容が刺激的であったということであろう。一般に地 理学研究が方向性の明確でない実証研究に甘んじる 傾向がみられる中で, 荒削りではあっても, 構想力 をもち仮説設定的アプローチを試みることは，問題 を浮き彫りにする上で大きな価值を有している。そ の意味でも同氏の今後の発展を大いに期待したい。

なお，本文をまとめる上で，発表時に記録をとっ ていただいた松尾容孝氏（鳥取大学）に多くを負っ ている。記して謝意を表したい。

河野通博：中国における人文地理学研究の動 向

駒井 正一

（1）報告の内容 本報告では, 中国の人文地理学 界の動向を解放前にまでさかのぼり, 具体的にあと づけて，検討を試みる。

1985年,「地理学報」 40 巻刊行を記念して, 地理 学教研活動 50 年以上の老大家 33 名が表彰された。う ち20名は人文地理研究者で, 自然地理専攻の任美鍔 なども, もとは人文地理研究から出発している。近 代中国地理学は人文地理学優勢の形で発展したとい える。彼らのうち, 地理研究者養成の温床であった 南京中央大学, 広州中山大学卒業の 9 名のほか, ケ ンブリッジ, シカゴ大, 東大や京大などで学んだ外
国留学組がめだつ。多くはその実績により, 解放後 学界の指導者に成長した。

解放後, 地理学界における最初の変動はソ連地理 学の影響をうけたブルジョワ地理思想批判と経済地 理学偏重および自然地理学・経済地理学の分離現象 である。前者は1952年からソ連の研究者の論説掲載 という形で「地理知識」誌上で開始された。批判の 対象となったのは環境決定論, 人種差別主義, ゲオ ポリティーク，アメリカの地理思想やマルサス人口 論などであり，ヘットナー，ハンチントンなどがや り玉にあげられた。中国人研究者による批判は1956 年からの張同鋳や孫敬之をリーダーとする中国人民 大学グループのものに始まる。ソ連地理学の紹介と ともにブリュンヌやクレッシー批判が行われた。こ のころから論説はいわば 1 段階 up して「地理学 報」誌上で展開され, 大学の地理系や中央・省レべ ルでの地理研究所増設もすすめられる。

当時の学界には “為人民服務” のもと, 実践的題 目として, 次の 2 つが課せられた。(1)総合調査：ア ムール・ウスリー流域調査（中ソ協力の形をとり, 後の調査のモデルとなる), 西南地区, 黄土高原西 部, 新疆ウイグルの調査など。青蔵高原総合調査へ と連続する。(2)中華経済地理志刊行（孫敬之編著。 自然地理誌編集と比し, 第 1 次 5 力年計画と連動し た経済地誌研究の早さがめだつ)。さらに，1958年 人民公社の出現にともない(1)地域計画の援助（公社 や大隊が単位)，(2)経済地域区分（自然地域区分に もとづく農業地域区分）の課題が加わった。ソ連の 研究者の引用が減少し, その後のソ連地理学の社会 経済地理学への新展開も学会誌上から消えていく。 そして, 中国の学界内部では理論闘争や提起が行わ れる。第 1 に, 地理学の対象は生産配置か生産力配 置かという問題である。孫敬之らのグループは生産 力配置にしぼり, 生産関係には言及しない態度をと った。事実，その場の大勢をしめていた。しかし， 1961年の経済地理シンポジウムでは生産配置論が優 勢をしめ, 孫敬之らの立場は逆転し, 曹廷藩や呉伝 鈞がリーダーになるというドラスティクな変化がた ちあらわれた。中国人民大学の影響は急速におとろ える。第 2 に, 鄧静中らによる生産地域総合体の概 念の提起である。この概念は経済地誌の研究対象と 
するのはよいとされたが, 経済地理学における位置 づけはペンディングとなったままになる。理論的に はソ連地理学から大きな影響をうけていたと思われ るものの，表面上その現象はうかがいえない。第 3 に, 地理学一元論の提唱である。従来, その時期ま でのソ連の影響をうけ, 経済地理と自然地理を明確 に分離する二元論が優勢であった。1961年から経済 地理学も点伝鈞らの自然地理, 技術科学と密接な関 係をもつ社会科学の辺縁科学とする一元論が台頭し たのである。ところが，1965年「地理知識」の編集 方針が大きく変化し，毛沢東思想が前面にだされ文 革前夜の姿をみせはじめる。ただ，この間に厳重敏 は上海近辺の農村経済の変化と中小都市の役割に関 する都市地理学に近い論文を提出しており，この時 期としては勇気あるかつ先駆的な仕事を残している。 文革が開始されると地理学はとりわけ大きな打撃 をうけることになる。「地理学をつぶせ」というの が文革派の主張であった。文革前期（1966～71年） には, 経済地理学はソ連直輸入のエセ科学であると し全面否定される。地理学者有害論が唱えられ, 多 くの研究者がつるし上げをうけ，迫害された。これ までの研究業績が没収されたり, 研究室そのものが 廃止されたりした。しかし，林彪事件前後には若干 状況が変わり, 周首相の援護のもと少なからぬ経済 地理研究者が元の職場に戻れることになる。再開後 の活動テーマは次のようなものであった。(1)農業地 理叢書の編集, (2)開拓可能地の調査, (3)エネルギー -工業中心の経済地域計画, (4)都市計画への参与 (とりわけ中小都市)。陝西・四川などの第 3 線地域 の建設も盛んに行われた。しかし，文革の被害は大 きく, 多くの地理研究者はその前途に絶望したり, 基礎研究をサボり, 外国での研究のフォローを意た らざるをえなかったことを後悔することになる。あ る程度の希望が生まれる一方, 依然として左からの 攻撃に萎縮していたのである。当時の偏向が色濃く みられるものとして『簡明中国地理』, 『中国沙漠概 論』（文革後改訂版出る）などがある。

文革後鄧小平路線が確立し，1978年に経済地理専 門委員会の全国シンポジウムが開かれた。報告書に は曹廷藩により地理学過去28年の総括が掲載され, 集会にも提出されなかった日米ソ地理の動向に関す
る論文を新たに所収し，国外にも再び目を開くこと になった。とくに，陳伝康はニュージオグラフィに ふれ, 経済地理学を除く人文地理学を社会文化地理 学とし, 自然地理, 経済地理をあわせた新しい総合 地理学の樹立を熱っぽく説いた。これがさそい水と なり, 中国地理学会第 4 回代表大会では人文地理学 の復活が全会一致に近い形で認められる。中国各地 では，まさに四つの近代化が始っていた。1980年, 東京の I G C には中国代表が姿を現わす。団員の一 人であった李旭旦は, 帰国後精力的に人文地理学の 復活に尽力し, 翌年には第 1 回人文地理シンポジウ ムの開催にこぎつけた。この集会はなお経済地理学 専門委の主催によったが, 人文地理学と経済地理学 の関係が問題となり, 結局, 後に経済地理学は人文 地理学の一分野にすぎないとの合意が形成された。 同年12月，全国人民代表第 4 次会議の席上，趙首相 から各級学校のなかで地理教育を強化せよとのお墨 付をもらい, そこから一挙に人文地理学復活の共通 認識ができあがった。第 6 次 5 力年計画では人文地 理学研究の推進がはかられる。胡喬木も中央党学校 での講話のなかで, 指導者の人文地理に関する無知 ・無関心が行政上にも多くのミスを誘発させている と批判し, 人文地理学習の必要性を強調した。いわ ば，第 2 の地理学の春をむかえたのである。急遽中 国百科大全書 - 地理学のうち『人文地理学』がまと められ, 人文地理専門委員会長張文奎の『人文地理 概論』が刊行された。後者は日本からの影響がきわ めて大きい。

このような状況のなか, 中国ではようやく人文地 理学が根を下ろしはじめたが, 次の点に問題が残さ れている。(1)歴史地理学が弱い（禹貢学派の伝統は あるが歴史学寄りで, 人文地理学との結びつきが弱 い)。(2)人文地理学導入が批判的摂取になっていな い（たとえば, 日本の高度経済成長の陽の部分に目 を奪われ，陰の部分を批判できない)。(3)政治に左 右されやすい（個人的りーダーの言により変化す る)。(4)隣接諸科学との連携が弱い（社会学などと の。これらの分野もまた発展途上にある)。(5)開発 にともなう矛盾への対応が弱い（沿海部中心の開発 政策に対し，少数民族地域開発の緊急性などが訴え られていない)。これらを克服していくことにより， 
中国の人文地理学は大いに発展していくことになろ う。

（2）討論〔籠瀬良明(日本大)〕 中国での“地 理”, “地理学”の一般的イメージは日本のそれと, どれくらいの類似性をもつか。

〔河野〕清朝以前 “地理”は風水の意に使われてお り，解放後も長い間経済地理一辺倒であったが，い ま人文地理といえぼ日本とほぼ同一の内容を指す。 最近，ヘットナーの主著の紹介が行われたことは， このことを象徴的に示すものといえよう。たた，観 光地理学の奨励が外貨獲得の実用的側面をもったり, 文化地理学が文化財地理学的うけとめ方をされたり している。学問としての理論の構造に弱点をもって おり，その概念も細かな点では日本と相違がある。 [張志偉(仏教大)]人民代表大会第 4 次会議の政府 活動報告における趙総理の発言は，地理教育のみを 対象としたものか，あるいは社会学など他の分野に ついても言及したものか。

[河野〕趙発言は愛国心の涵養のため, 中国史と中 国地理の重要性を訴えたものである。胡喬木発言は 行政官, 各地域指導者が社会・文化的な広い知識と くに民族問題に対する正確な理解の必要から述べら れたものであり，趙発言と少し異なる。

[戸所隆(立命館大)] 人文地理学の復活過程で地図 の作成・利用はどのような状況にあるか。また，都 市地理研究や都市開発などに詳細な地図が使われて いるのではないか。

〔河野〕外国人は原則として 5 万分の 1 図は使えな い。中国内部では地域計画に際して使用されている が，日常の大学教育には利用されていない。ただし， 例外もあり, 北京大学の炭田地域の工業配置計画で はゼミの学生も地図を利用していると考えられる。 50 万分の 1 図は衛星写真をもとに地形図，土地利用 図などが統一的に作成されており，まもなく完成す る見达みである。

[石原潤(名古屋大)] 大百科全書『人文地理学』に は中心地学説, パーセプションと行動地理学などの 項目がみられるが，西側先進国の資本主義体制下で 構築されたこれらの理論やモデルは計画経済，人口 移動の制限の行われた中国でも有効と考えられるか。 [河野〕 中国では百万都市の厳重な人口流入規制の
一方で，中小都市の都市化が計られている。また， 北京・天津・唐山や江南デル夕など広域の地域開発 では，メガロポリス論と結びついた問題がとりあげ られている。しかし，現状は先進資本主義国での研 究・理論の摂取段階にあり，今後それらに対する反 省・批判が生じると考えられる。

〔斎藤光格(神戸大)〕ブルジョワ地理思想批判でと りあげられた人種差別とはどういう内容のものか。 また，ソ連から導入された考え方に，欧米・日本な どと異った新しい観点はみられるか。

〔河野〕人種差別とは白人優越論のことであり，八 ンチントンの『気候と文明』などがやり玉にあがっ ている。また，批判自体には目新しいものはなく， グローバルジオグラフィに対する批判もアメリカの 世界戦略に対する批判が地理学に導入されたもので ある。

[竹内啓一(一橋大) $]$ 中国での講義の機会があった が，受講生の反応から中国地理学は摂取一方で，基 礎にあるべき現実への批判精神に立脚していないよ うに感じられた。これは, 西欧の計量地理学を無批 判的に摂取したもののそれへの批判地理学をうけ入 れていないツ連地理学についてもいえることである。 中国の学界に，批判的精神をもった真の人文地理学 が育つ可能性があるのだろうか。

〔河野〕来日した中国の地理研究者は高度経済成長 に日本の地理研究者がいかなる貢献をしたかをよく 尋ねるが，多くの場合批判には言及しない。批判点 にはいまだ目がむいていない段階にあり，今後，下 からの批判が生れるには，もう少し時間がかかると 思われる。

（3）座長の所見 本報告者の河野通博氏は文革前 から中国地理学との交流活動を活発に行なってきた。 また, 日中地理学会議の会長を務め, 中国地理学界 の実情に通暁されている。氏はこれらの経験をふま え, 解放前の中央大学や中山大学などの少数の地理 学研究者養成から出発し, 解放後のソ連地理学の無 批判的導入と訣別，文革期の学界の混乱とその克服， 人文地理学の再生について研究者とその論説・行動 など具体的な事実を示し，説得性ある報告を行った。

文革当時, われわれは中国科学院地理研究所の署 名入りで「研究所の走資派は地理学に“神通力”を 
もたせ，区画，区画と称して紙上の空論をつくり， 笑い話にしたてあげている」との人民日報の記事を みている。つまり，農業区画工作や詳細な報告書が 専門家, 権威ぶっていると非難する文革派に研究所 が乗取られたわけで, 中枢が冒されて地理学の再生 はありうるのかと考えたものである。本報告で, 迫 害されたり, 研究の場を離れざるを得なくなる人が いたことに言及している点に対応する。だが，文革 終了後の1978年には復興が開始される。時間の制約 上, 報告者はくわしくふれなかったが, 第 6 次 5 力 年計画では, 哲学・社会科学部門の発展がめざされ, 社会学・民族問題など 12 の重点のほか, 人文地理学 は新聞学や図書館学とともに“これまであまり研究 されていない学科”の強化の一貫として組みこまれ ることとなった。

報告者も指摘したが, 復興後の人文地理学は日本 とほぼ同じ内容をもつ。とはいえ, 人文地理専門委 員会の初代主任委員であった故李旭旦の意見に代表 されるように，目下のところ社会・人文システムと 自然システムおよびそれらの内在的関係を研究する 人地関係論を基礎とするものが主流をしめる。した がって, 地理学における統一性と総合性の強調もな されることとなり,ヘットナーなどの再評価も統一 的地域の方法論を唱えている点が見直されていると みるべきである。これと同じ理由により，自然環境 と人類生活の調和論 (中国地理学でいう和諧論)を 説いたとするソ連のアヌーチンらの統一地理学も一 定の評価をうけた点を理解することができる。報告 者は「中ソ訣別後, 中国が生産地域総合体の理論を 構築したとき水面下でソ連地理学の影響があったは ずだ」と指摘した。影響を与えた主体はまさに，当 時のアヌーチンらの地理学であった。ソ連地理学も また人間のでてこない自然地理と生産関係を偏重し 自然条件を捨象した経済地理学との乘離をおそれた のである。

報告者は人文地理学の復興にともなう外国地理学 の導入が無批判的であるなどの点を問題にした。一 方で, 人口規模と都市の構造上の変化や農村の都市 化にともない, 農業人口に属しながら郷鎮企業など の非農業活動に従事する “亦工亦農” 人口の出現な ど, 人文地理学のめざす対象は近代化のなかで急増
している。中国人文地理学は，しばらくはこのよう な現実の課題に対応しつつ批判の必要性を自覚し, 試行錯誤をへて再生していかざるをえないといえよ 门。

なお，本稿をまとめるにあたっては，当日書記を 担当された小島泰雄氏（京大・院）の記録に負うと ころが大きく, 記して感謝の意を表したい。

松山利夫：アーネムランド・アボリジニ， ジ ナン族の空間区分

松本 博之

（1）報告の内容 オーストラリアの原住民アボリ ジニについては, 1950年代, 機能地域概念の検討や 新たな地域理論の構築をめぐって，すでに詳細な検 討が行われている。報告者はそうした先学の業績を 念頭におき, 中部アーネムランドのジナン族（現在 約 200 人）をとりあげ, 彼らの空間区分について報 告する。アーネムランド・アボリジニ（現在約 10,000 人， 30 部族，ここでの部族とは第一言語を母 語にする集団の意) の近年の動向をみると, 中部ア ーネムランドでは，1950年代中頃から1960年代にか けて，伝統的な領域をはなれ，北部海岸の「まち」 (Aboriginal Town, Maningrida) に集住する。そ のことが, 多くの人間の存在 $(1,500$ 人) と異部族 との混住のために, 社会的な混乱と緊張をもたらし た。そのため, 1970年代のはじめから，「まち」を はなれ，伝統的な領域へもどる Outstation Movement がおこった。報告者の調査地ガマディは 1975 年に新たに建設されたアボリジニの「むら」Outstation の 1 つである。彼らは今日, 食糧の一部を 「まち」から供給される一方, 食糧の $50 \%$ を散弾銃 ・ライフル・トラックを用いた狩猟・漁撈によって 獲得する「現代の狩猟民」である。

そうした現代の狩猟民の参与観察にもとづいて報 告するが，より具体的な報告の目的は，(1)新たに建 設された「むら」の領域や旧来からの氏族・部族の 領域が,アボリジニにとって，「むら」建設のさい の居住地の選択やことなる生態系での資源開発を制 限する要素にならないこと, (2)そうした領域の境界 の不明確な性格は彼らの親族関係のありようと神話 に深くむすびついていること, つまり, アボリジニ 
の空間を秩序づけるものは彼らの神話であり，区分 された空間の領域性というものは彼らのトーテム Dreaming の反映であることを明らかにしたい。こ の目的を達成するために，次の 2 つの方法を採用す る。（I )参与観察した，日常的な資源開発行動の記 録にもとづいて，彼らの空間の利用と区分の実態を 把握する。区分された空間を資源開発の技術や親族 関係と関連させて検討することにより，彼らの空間 の意味づけを明らかにする。（II）そのようにして析 出された意味を有する空間の背景にある論理を知る ために，環境と人間との関係を語る神話とそれを象 徵的に表現する儀礼を分析する。

（I）ジナン族の領域は 3 つ生態系をふくむ $1,800 \mathrm{~km}^{2}$ におよび，ガマディ「むら」は森林・湿 地複合生態系にふくまれる $180 \mathrm{~km}^{2}$ にわたる。こ の「むら」の空間は建設にあたって選択されている。 この土地は本来イリチャ半族のウラッキ氏族に属す るが，「むら」の成員（20人）には，ウラッキ（7 人）ばかりか, ドゥア半族のモロゴン氏族（ 8 人), 後者との婚姻を契機として加わった他部族の人びと （5人）もふくむからである。

この土地での，彼らの資源開発は狩猟・漁㧗によ る食糧と神話・伝説を描く木皮画（これは市場向け の商品ともなる）の材料の獲得という二面にわたる。 前者の主たる対象はカササギガン，ワラビー，カメ， 魚介類である。それらの狩猟地・漁掞地は，季節的 に棲息地をかえるカササギガンが一時隣接部族との 緩衝地帯で狩編される点と，魚介類のほとんどが隣 接するブララ部族の領域内で漁掞される点をのぞけ ば，この「むら」の空間内におさまる。一方，後者 は木皮と 4 種の顔料から成り，白の顔料が隣接部族 の領域内で採集される以外，これらも「むら」の空 間内で充足される（但し，赤の顔料は町から購入）。

次に，集落とその周辺での生活行動に目を移すと， 集落の近隣の疎林にゴミ捨て場，少し遠方に墓地が ある。集落内の中心部に儀礼の催される空地（日常 生活では, 自由に通行が可能）がみられる。空地を とりまく複数の家屋には，それぞれ二世代家族が居 住するが，儀礼のおり，招待された「むら」の非成 員は，ドゥア半族とイリチャ半族を問わず，「むら」 びととの親族関係の遠近におうじて，各々の家屋の
脇に camp site を設営し, 集落の内部ですみわけ る。

以上のように，日常生活での空間利用は，若干の ものをのぞき，「むら」の領域内でほぼ完結する。 それゆえ，「むら」の領域は居住者たちにとって最 も基本的かつ重要な空間である。こうした集団が伝 統的にホルド（ないしバンド）とよばれる。ただ， 注目すべき点は「むら」の非成員がその領域内で食 糧その他の資源を開発する場合，領域を管轄するリ ーダー（モロゴン氏族の者）の許可を得るか，「む ら」の成員の带同を期待されることである。

ところで，こうした「むら」の空間は孤立してい るわけではない。アボリジニの婚姻制度である氏族 外婚・部族外婚を契機として，外部世界とつながる。 ガマディの場合，ウラッキとモロゴンとの婚姻が 4 例，モロゴンと他部族ブララとの婚姻が10例を数え, 前者が同一部族内の隣接空間との連絡を，一方後者 がより遠方の空間との連絡を拡大する契機となる。 このことが他氏族・他部族の領域内の，自らとはこ となる生態系での資源開発を可能にし，先に述べた ブララ族領域内での魚介類や白粘土の開発がそのこ とを物語る。しかし，この場合にも，他氏族・他部 族の成員は在地の「むら」びとの許可を得て, その 土地の精霊に紹介されることが期待される。それは， 他氏族・他部族の成員がその土地の精霊と直接的か つ濃密な関係をもたない，と考えられているからで ある。そうだとすれば，このガマディ「むら」にと り，他氏族であるモロゴンの人びとについて，この 土地の精霊とのかかわりを問いなおさなければなら ない。そのためには，この地のアボリジニの有する 「土地の精霊との直接的かつ濃密な関係」という領 域観の背後にある論理をさぐらなければならない。

（II ）ジナン族の創世神話によれば，創世神である 二人姉妹チャンカオとマンボが旅の途次祖先の精霊 の象徵である「明けの明星」をつかみ，かつて水ば かりであった所に，東ないし北方から到来し，ジナ ン族の大地ガッチャラーラとトーテムの動植物をつ くる。その大地を氏族の土地に分割し，各々の土地 にトーテムであり，人びとの食糧ともなる動植物を 集める。トーテムは旅をしながら，各々の土地に泉 や川などの地形をつくり，今もそこに棲みつづける。 
一方，人間の登場については何も語られないが，創 世神は人びとを男女各々 4 つのグループ subsection に分割して，相互に結婚すべき相手の subsection を決定する。つまり, 創世神がアボリジニ の生活する領域と, その土地に根ざしたトーテムで あり人びとの食糧でもある動植物をもたらし, 現在 もアボリジニの守るべき生活規範の多くを定めたわ けである。

さらに, 生みだされた土地, 特定の生態的ニッチ エを有する食糧・トーテムの動植物，およびそこに 暮らす人びとは相互に遊離しているわけではなく, それらの間を精霊が循環する。人の死を契機として， 人は精霊になり, 精霊の地である泉にもどる。泉の 精霊はそこにやってくる動植物（トーテム）に宿る ことにより，食糧としての生物種は維持される。す なわち, 人間と特定の土地とその地のトーテムとは 精霊を媒介として一体化し, 直接的かつ濃密な関係 を有するのである。それゆえ, アボリジニのある個 人がその地の精霊の循環系と濃密な関係をもたない 場合, 資源開発にさいして, 濃密な関係をもつ者に よる精霊への紹介が望まれ，土地の成員による带同 が彼らの世界では現実の行為として期待されている と思われる。したがって，モロゴンの人びとは当初 ウラッキの土地の精霊と濃密な関係をもたなかった はずであるが，日常的な動植物の捕獲を通じてトー テムに働きかけ, 日々それらを世話し, ウラッキ氏 族のトーテムや土地とのかかわりを深め, この領域 への移住を可能にさせたと考えられる。

ところで,こうした土地とトーテム (食糧) の動 植物と人間との一体感はアボリジニにとってたんな る神話上の思弁ではない。それは神話のなかの出来 事を表現する木皮画の製作や儀礼の行為によって再 確認され, 強化される。たとえば, 彼らにとって最 も重要な, 二週間におよぶ「明けの明星」の儀礼で は, ディジャリドゥを吹き，チャントをロずさみな がら, 精霊たちをよび集め, 集まった数多くのトー テム（祖先の精霊）を聖なる柱に克明に描きこみ, 最終的には，宇宙を旅する始源の祖先の精霊である 「明けの明星」の人形マラジュレに仕上げられる。 儀礼の最終段階では，このマラジュレ(御柱) をガ マディの集落の中央の大地に据え, 人びと自らはト
ーテムと化して踊り，この世に存在する精霊の土地 としての大地ガッチャラーラと, 宇宙を旅する祖先 の精霊の星との一体性が象徵的に表現される。ガマ ディ「むら」の人びとは, 精霊やトーテムの動植物 とむすびついた自らと, 氏族や部族の領域を,「明 けの明星」の儀礼をとおして, 壮大な宇宙空間のな かに位置づけていると思われる。

(2) 討論〔小林健太郎(滋賀大)〕狩猟・漁掞活 動はどの程度の頻度で行われるのか。

〔松山】117日間の調査によると, 乾季ではカササ ギガンへの依存率が高く, 頻度としては0.5回/日 (儀礼期間は 0.7 回/日), 1 人当たり平均可食料は $614.2 \mathrm{~g}$ (同321.9g ) にのぼり, ワラビー, カメ, 魚介類は補助的位置にとどまる。乾季末から雨季初 にかけては湿地の乾燥により, カササギガンが遠方 に移動するために，ワラビー（0.4回/日，552.1 g ), 魚介類 (0.5回/日, $139.9 \mathrm{~g})$ への依存率が高く, カササギガンは補助的である。

[小林] 他部族との婚姻がことなる生態系での資源 開発を可能にすると言われるが, 部族外婚の相手部 族の選択はどのような基準・契機で行われるのか。 〔松山】選択の基準・契機については，今のところ 不明。ジナン族は昔からブララ族ときまっている。 アボリジニは一般に女性交換を行う。彼らは東の人 は西の人と, 内陸の人は海岸の人と交換すると言う。 系譜関係をみると，交差イトコ婚が多い。

[小林］スライドのなかで森林に火入れをする光景 が見られたが，何のために行われるのか。

〔松山〕一般的には，環境をコントロールすること， つまり，(1)獲物の追出 (2)下生えや落葉の堆積が乾 季に自然発火し, 惨事を招くが, その防止 (3)本来 なら，この地では亜熱帯モンスーン林となるが, 獲 物の棲息環境として望ましい疎林状態の維持, など があげられている。ただ，ガマディの人びとは，(1) 獲物の追出, (2)狩猟のさいに歩きやすくすること, (3)清掃という理由をあげる。

〔千葉徳爾(明治大非常勤)〕行政側が諸部族を Aboriginal Town に集住・定着させたということ だが, そうした措置を講じた理由と, その当時行政 側のアボリジニに関する知識はどの程度のものであ ったのか。 
〔松山〕アーネムランドでは，19世紀からキリスト 教の各会派が Mission Town を建設する。その目 的は(1)キリスト教の布教 (2)教育 (3)政府のアボリ ジニにたいする同化政策の回避であったが, 各会派 のアボリジニに関する知識はそしく，「まち」での 儀礼は禁止され, 儀礼のおりには, 一時森へ移動し ていた。政府による Aboriginal Town 建設の動機 はアーネムランドの産物（ワニ皮，木材）の交易拠 点の確立であった。建設にアボリジニが動員され, 貸与された住居にそのまま居つく形で, 移動が抗こ った。当時は, 白人社会への同化政策が推進されて おり，アボリジニを理解するというより，事実上そ の社会・文化を消滅させる方向に動いていたと思わ れる。

〔千葉〕再び「むら」を建設するさい, 行政側は関 与しなかったと思われるが, 再居住のための領域選 定はいかにして行われ，またそのための資源利用の 技術はいかにして獲得されたのか。

〔松山〕ウラッキの人びとにとっては，自己の氏族 の領域であったこと。一方, モロゴン氏族の人びと にとっては，とくに現在の「むら」のリーダー（モ ロゴン）の母親がウラッキ氏族の出身者であり，一 般的に言えば，この地は「母のカントリー」にあた り，それが選定の重要な理由である。また，1961年 頃, 散弾銃の使用が許可され, 旧来の槍投げ器と槍 に替っている。再移住にさいして, 政府は住居材の トタンの支給, その他トラクター, 建設用具, 無線 電話器の貸与, 井戸の開削などを行っている。

〔大島襄二(関学大)〕 集住期に, 政府側から新たな 食糧生産や技術の指導はなかったのか。あったとす れば，再移住後の現在の生活にどのように生かされ ているか。

〔松山】食糧生産の技術指導については, 正確に把 握していない。しかし, トラクターやトラックの運 転・修理技術の指導, とくに木皮画やカゴ類など, 伝統的な art and craft 復活の技術指導と買上げ, 積極的な市場開拓が半官半民の会社によって行われ ている。

[大島】多部族の集住期に, 伝統的な形式とはこと なる部族間の婚姻はおこらなかったのか。

[松山]伝統的な婚姻形式は, promised wife と
して，母方のオバの決める二世代下の, 創世神話に 指定された sub-section の女性と結婚するものであ るが，今日それに該当するのは $3 ， 4$ 割である。今 日, sub-section の規範に抵触しないかぎり，「盗ん だ妻」と表現される同世代間の婚姻が増えている。 正確な数值は把握していないが, 以前もこうした婚 姻がかなりあったのではないかと考えている。本来 なら，ジナン族はブララ族との婚姻であるが，集住 期には, ほかの部族や白人・日本人との婚姻も存在 した。

〔大島〕1975年のガマディ「むら」建設以前，この 地域はどのような状態であったのか。

〔松山〕聴き取りによると，マニングリダ建設の 1957年頃には，それぞれ 1 ないし 2 家族から成る, いくつかの camp site が散在していたらしい。 [大島〕「まち」から供給される食糧と従来からの 狩猟・漁撈で獲得される食糧とは, 分配など, 取り あつかいの点で，どのような違いが見られるか。 [松山] 政府から供給される小麦粉・缶詰などの食 糧は失業手当や寡婦年金などの社会的給付金によっ て購入される。購入食糧は誰かに要求されないかぎ り，配分されないが，一方自給的食糧は，かならず しも平等でないとしても，「むら」の構成員にはす べて配分され，両者の意味づけは大いにことなる。 〔池野茂(桃山学院大)〕 クインズランド州では, 生 活空間の境界にたいするタブーがあり, アボリジニ は境界を越えることに抵抗感を抱くと聞いているが， この地域ではどうか。

〔松山〕状況によると言える。ジナン族とブララ族 やレンバランガ族のように，外婚を行っている場合， 境界を越えることにほとんど抵抗感はない。しかし， 自己と関係のうすい氏族や部族の領域への侵入にた いしては，強い抵抗感を有している。ただ，今日四 輪駆動車の導入が境界のタブーに関して, 大きな変 化をもたらしている。

(3) 座長の所見 アボリジニの「領域」Territoriality の問題を手がけるには, 覚悟してかからなけ ればならない。それは, 松山氏の報告に示されたよ うに, その問題がふくみこむ内容の広範さ, その地 方的なヴァリエーション，それにアボリジニが「ア ボリジニとして生きること」の微妙な部分にかかわ 
らなければならないからである。この問題にとりく む「よそ者」としての研究者は，自己の文化的背景 をになった概念や思考法とアボリジニにとってのリ アリティとの乘離のジレンマにつねに悩まされる。 既成の客観的・論理的な認識による概念にたよると， アボリジニの「領域性」のリアリティにくさびを打 ちこむことにもなりかねない。それを避けるために は，まずはアボリジニの「生きられた世界」に深く 入りこみ，その息吹を十分に吸いこんで，感性をも ふくめた調査者自身の足場をたしかなものにする必 要がある。松山氏が採られた方法はまさにこれであ り, そのため, 氏の報告から, なじみのうすいアボ リジニの「領域性」について，かなり鮮明なイメー ジを描くことができたのは，私だけではあるまい。 松山氏の報告の目的・方法は明確であり，つけく わえるべきものはない。しかし，その問題をすこし 一般化して考えるならば, (1)ホルド (バンド) の構 成の柔軟性，(2)無制限ではないとしても，氏族領域 ・部族領域にとらわれない資源開発の可能性という 松山氏の指摘は従来の，狩猟採集民社会に関する J. H. Steward の「父系バンド」や A. R. Radcliffe-Brown の「ホルド」の概念内容に反省を迫る ものである。それにもまして，人間が土地を領有す るのではなく, 精霊を媒介とした人間・動植物（ト ーテム）・土地の三位一体観にこそ，アボリジニの 「領域性」の本質があるとする指摘は，狩猟採集社 会の「領域性」を実践的な生業活動の空間的側面で のみ探究してきた従来の研究に, 当該の人びとの有 するイデオロギー的側面をも考慮することの必要性 を迫っている。この点は, かつて水津一朗氏が「精 神的風土」として, その重要性を指摘したまま，そ の後経済的要因主導型の地域理論の蔭にかくれてし まったが，松山氏には，今後も継続されるアボリジ 二の研究をとおして，こうしたイデオロギー的側面 をもふくむ，新たな地域理論の構築を期待したい。

さらに，1970年代の Outstation Movement をむ かえるまで，19世紀から進行した政府・ミッション によるアボリジニの Town への集住化のために, 最も白人の影響の少なかったアーネムランドにおい てさえ，アボリジ二の狩猟採集活動の正確な把握は 皆無に近い状況であった。その意味でも, 松山氏の
提示された生業活動の記録は貴重である。ただ，私 はアーネムランド・アボリジニの調査経験をもたな いので, 判断しかねているが, あるアボリジニの個 人と「母のカントリー」やその地の精霊とのかかわ りについて，アーネムランドのほかの調査事例（ヨ ルング族, ギジンガリ族，ダラボン族）によると, 在地の氏族員と同等ないしそれ以上の濃密な関係を 有すると考えられているようであり，その点を今後 も継続される調査のなかでたしかめて頂ければ，幸 いである。

なお，本稿の作成にあたって，発表当日書記をつ とめられた大阪市立大学院生の年代雅夫氏の記録に 負うところが大きい。記して感謝したい。

山本 茂: 東欧諸国の地理学的研究について 一社会経済発展の空間的不均等の視 点から一

中村 泰三

（1）報告の内容 本報告は東欧型社会主義論，あ るいは地域的不均等発展論との接点の周辺に問題を 設定し，東欧地域の社会主義の実情について一つの 解釈を行い, 地域的な不均等発展論研究に参加する というのが直接的な目的である。この問題を取り上 げる際に，(1)地域的不均等問題の理論的あるいは理 念的なレベルでの問題, (2)地域政策に関わる政策レ ベルでの問題, (3)地域経済の実態という三つの分析 視角を設定して考察を行い, 最後に地域的不均等発 展の問題，あるいは社会主義下での地域経済のあり 方について言及する。事例としては主としてポーラ ンドの場合を扱うが，そこで出てくる問題の性格は, ある程度まで東欧諸国に広く普遍性を持つものと考 えられる。

(1)現存社会主義における地域政策の理念と目標 社会主義が諸個人の社会的な平等, あるいは社会 的な公正を実現するための思想・運動・現実である とすれば社会的な不平等を解消するためには，その 不平等の発生のメカニズムを除去することが政策的 に必要となる。地域的平等は社会的平等の空間的側 面をなし, 社会主義経済体制では地域的平等を実現 するために地域政策をとる。地域政策の基本的目標 は, 地域間格差の平準化，もしくは地域的平等化に 
よって, 国内のより発展した地域とより低開発な地 域との間のギャップを縮小することである。地域計 画は総合的な国家発展計画の一部であって, 社会経 済生活の全ての側面を含み, その執行は各レベルの 政府部門によってなされ，全国の全地域を政策の対 象としている。

Fuchs \& Demko（1979）の研究は社会主義と地 域的不平等をめぐる最近の研究成果についてのサー ヴェイ論文として，また通説的な見解をきわめて鮮 明に代表している点に扔いて注目される。すなわち， 社会主義経済は, その存立の理念から言って地域的 不平等を発展，拡大させる物質的な基礎は存在せず, 社会主義経済下の地域経済は平準化・均等化される はずであるが, 現存の社会主義社会には著しい地域 的な不均等がみられる。従って, 現存社会主義の地 域政策というのは本来の社会主義に忠実でない性格 を持っているという主張である。この通説は, 資本 主義経済の本来的性質から派生する地域経済発展の 不均等性と社会主義経済の均等発展モデルとが, ま さにネガとポジの関係として位置づけられ，そうい う対応関係の下で, 理論的に根拠付けが充分になさ れないまま無批判に踏襲されている。しかしながら， 果して社会主義経済における地域政策の基本目標を 地域経済の均等発展に置くという考え方自体をこう した位置づけで理解していいのかどうか, さらに厳 密に理論的に検討されなければならない。

(2)地域政策の歴史的推移とその問題点

ポーランドにおける戦後 40 年間の地域政策を通暁 すると一貫した流れと言うものは存在しなかったと いってよい。地域的な均等発展理念は1950年代の六 か年計画とその修正期において最も強く表面に登場 し，「最も重要かつ緊急な原則は全国にわたる工場 の, より均等な配置を実現することである」という テーゼで集約されるような地域政策が推進された。 しかしながら，60年代以降になると，均等配置理念 は実質的な修正がなされ，70年代にはいると地域的 な集中を積極的に評価して，その下で国民経済の空 間構造理念を探求するという, 理念の一種の転換が ギエレク成長発展戦略によって全国的に展開される ようになった。都市工業アグロメレーションの積極 的評価はまさにこのことを意味している。この空間
計画思想は, その起源を1930年代後半の中央工業地 域計画に求めることができる。

このようにポーランドの地域政策史は，大きくは 経済効率性原理と地域的な均等化理念という二つの 理念の対抗の中で把握することができる。しかし， 実際には地域政策においては経済効率性原理に終始 プライオリティが与えられていたといえる。このこ とは, 地域的均等への配慮が投資の総コスト，ある いは生産コスト全体が同一の場合のみ作動するよう なメカニズムを社会主義経済がビルトインしている 限り, 均等化理念が本来的に追求できないメカニズ ムになっていることに由来している。また, 地域政 策の実践によってどの程度地域的不均等格差の縮小 が実現できたかに関しては, 地域的な不均等性は長 期にわたって安定的, 固定的であったという現実が 明らかになった。このことの背景には, 資本主義か ら引き継いだ歴史的遺産の問題と共に, 経済建設を 最優先する経済政策や工業立地の自由選択度の減少 も関与している。

このように, 地域経済の均等発展は, 必ずしもそ れ自身地域政策の目的ではなく, 経済政策の課題を 実現するための手段として考えるべきものである。 地域経済に不均等が長期にわたって存在するのは, それなりの根拠があるからである。それは, 国土の 自然的賦与の空間的不均等分布, 産業部門間の不均 等発展, 都市・人口の発展と分布の不均等, 現在の 生産力水準がなお距離の制約を経済的に克服できな い水準にあることなどの結果である。

(3)地域経済発展の実態と動向

ポーランドにおける地域経済の発展の実態と動向 を最大の行政単位 (県)を計測単位として 32 の指標 群 (基礎的指標群, 経済的·生産的指標群, 社会的 - 文化的・生活的指標群）をもとに分析すると以下 のことが明らかとなる。

まず, 地域経済の発展水準には 3 つのレベルが存 在する。すなわち, (1)相対的な先進地域である上シ ロンスク工業地带を含む南部・南西部地域, (2)中位 の発展水準にある北部・中西部, (3)最も後進的な中 央部, 北東部, 中東部, 南東部である。この格差は 戦前までの時代に形成された地域構造そのものであ って, 分割期のドイツ領地域と, ロシア領・オース 
トリア領地域との対照を継承している。また, 指標 群のうちには, 賃金水準, サービス業販売額など比 較的地域差が少ない指標がみられるが, ソ連国境に 沿う地帯は，そうした諸指標においても概ね低位の 条件を持つ地域である。こうした「弱い県」の経済 発展の問題は, 70 年代の中葉の地方制度の改正を契 機に表われてきたようにみえるが，実はポーランド の地域問題と地域政策の根底に位置づけられる長期 にわたる問題である。

次に, 経済的指標群についてみると, 平均以上の 数值を示す大都市県, 地方的中心県, 鉱工業都市県 の三類型が検出され, 概ね北部 - 中西部, 南部, 南 西部に該当しており，ポーランドを大きく二分する 東西のコントラストが明瞭である。他方, 社会的指 標群に関しては, 大都市県の優位は基本的に継承さ れているが, その他の県間では指標によって大きな 凹凸がみられる。この格差を変異係数並びに上位・ 下位各 5 県間に存在する偏差で評価すると, 工業に おける大きな地域間格差と農業における小さな地域 差が対照的である。一方, 賃金水準その他の経済的 な指標群では地域差が非常に少なくなっており, 国 民経済の等質化が進んでいるものと推定される。総 じて, 経済的指標群でみる地域間格差は, 工業を別 とすれば比較的少なく, 偏差でみても $1: 2$ 前後に 収れんしているが，社会的指標群においてはばらつ きが大きい。すなわち, 住宅・教育などでは均質化 が進んでいるが，医療・鉄道などでは地域差がかな り大きい。

問題は, 社会的な指標群と経済的な指標群との間 に有為な差があるかどうかということであるが, Hamilton, F. E. Ian（1982）のように大胆に結論を 導き出すことはできないように思われる。Hamilton の場合, 経済的な過程においては地域間格差は 非常に大きいが，社会的過程においては少ないとい う結論を出しているが, 今回の分析ではこの見解を 支持する有力な根拠はみられなかった。むしろ, 同 じ経済的な指標においても, 富とか所得の形成局面 よりも分配, 消費に関わる指標において一人当りで より平等であって, 社会的指標群では地域差に大小 の相違はあるが, 地域生活の基本的な側面で地域差 は検証できない。一人当り固定資産額ではきわめて
均質で, 生産的なそれよりも非生産的な固定資産額 において,さらに等質化が進んでいることは明瞭で ある。総じて, 内部に一定の格差を含みながらも, 大きくみればポーランドの社会・経済の地域間格差 というものは顕著ではなく歴史的な傾向としても格 差の縮小を指摘することができる。

(4)まとめ

以上の検討を踏まえると, 「社会主義の下での地 域的不均等」論の再構築の方向は次のように考えら れる。地域政策が成立するためには経済体制の如何 にかかわらず, 一定程度の生産力発展水準, 国土空 間の高密度利用が前提である。生産条件の結果とし ての不均等ということと生活条件の均等化, 諸機会 の平等化とは分離して考察する必要がある。地域政 策の目標として重要なことは, 生産レベルの地域的 な不均等の存在にもかかわらず, 諸個人の生活条件 を均等化し, 住民生活の諸機会へのアクセスの平等 を制度的，実質的に実現することであって，その際， 社会的総所得の形成, 所得配分, 個人的, 社会的消 費の関係を切断して, 社会主義的経済管理の利点の 一つである再配分メカニズムの作動により国民経済 の空間構造を前記方向へ誘導することである。従来, 一部には地域的不均等の内容を充分に考察しないま ま同義反復にも似た非生産的な議論に陥ることもあ ったが, 現存社会主義の地域的な現実を冷静に確認 して, 客観的な事実を積み上げた上で政策批判に注 意を向けていくという方向が, 我々のとるべき発想 ではないかと思われる。

（2）討論〔水岡不二雄(一橋大)〕 本報告にある ような社会主義社会における平等化・均等化の理念 は社会主義発展のどのようなレベルで問題にされて いるものか。私見によれば, 社会主義社会が共産主 義社会へ発展して行くにつれ社会の経済環境の平等 化・均等化にも政策が向かって行くと考えられる。 本報告におけるポーランドの事例・理念は一つの社 会主義社会の発展段階において中間的なものとみな し得ると思うがどうか。

〔山本〕どの様な歴史的条件, 空間的条件を持って いる社会主義であれ，本来的に生産力分布は，かな りの程度不均等にならざるを得ない。それゆえ, 本 報告で取り上げた地域政策の理念は中間的な, ある 
いは生産力の未成熟なポーランドにおいて個別的に 通用するというよりも，原理的には，かなり長期的， 普遍的に社会主義の国土政策一般に妥当すると思う。 〔松原宏(西南学院大)〕工業部門において地域間格 差が大きくなることを強調されたが，それはポーラ ンドの工業が原料指向的工業に特化しているからで はないか。市場指向的，もしくは立地自由度の高い 機械工業などが発展してくれば均等化の方向が生ま れてくるのではないか。

〔山本〕立地の自由度の大きい産業部門が一国の国 民経済の主導部門となった段階においては，立地誘 導が非常な効果を発揮するわけであるから，原理的 には不均等は解消できる。しかし，解消すべきかど うかについては他の立地要因との関係を考慮する必 要がある。

[中村泰三(大阪市大)] 最近社会主義国の地理学に おいて従来の狭い意味での経済地理学という立場か ら社会的なファクターを重視する経済地理学に变わ ってきているが, このことと地域的均等発展の問題 とはどういう関連があるか。

〔山本〕確かにポーランドでも社会的ファクターを 重視するような研究動向は非常に強い。本報告との 関連でいえば，生活条件を均質化する場合，その基 礎をいかに設定するかという具体的, 実践的な問題 との関係において, 社会的あるいは経済以外の生活 側面と, それの地理的な配置, あるいは空間構造を 考慮することになると思われる。

〔富樫幸一(岐阜大)〕・ポーランドに扔いても工業の 地域的な集中・分散の問題が重要視されているよう であれば, 体制は異なるとはいえ, 日本の工業の地 域構造研究の観点からすると, 各産業部門の地域的 分業体系の内容が重要なのではないかと考えられる。 このような地域的分業の問題は社会主義の場合はど うなのか。

〔山本〕ポーランドの地域的な分業体系には, (1)素 材から最終製品に至るまでの総合的な完結性を持つ 上シロンスク工業地带, (2)補助的な地方的工業地带, (3)点的な分業生産現場である地方都市という 3 レベ ルが存在し, 国全体の工業生産システムの階層構造 を形成している。しかし，おのおのの内部がどうい う構造になっているかについては今後の課題として
考えていきたい。

(3) 座長の所見 興味ある問題提起であり, 日本 との関連で質問も出て, 活発な討論が期待されたが, 全体として質問者が少なく，やや盛り上りに久けた のが残念であった。

発表者の地域の均等発展に関する問題の検討と論 議の展開は明確である。たしかに，指摘されたよう に, 地域の均等化の中味に対する厳密な検討がこれ までなされず, 資本主義体制では地域の不均等発展, 社会主義体制では均等発展が生じるという題目で終 っていた観があったのは事実である。

発表者の工業発展の地域的不均等, 社会, 所得分 野での均等性という主旨は, ソ連では政策立案者が 十分ではないが，すでに採用していると考えられる。 発表者の主旨は社会主義国一般にあてはまる図式で あろう。ただ, 論者がポーランドを例にとられたの で，ソ連やユーゴスラビアのような多民族国家では， 民族問題に対する考慮があって経済的合理性の追究 だけでは問題が納まらないように思われる。

また，討論時の質問と関連するが，発達した社会 主義の段階での地域構造のスケッチは発表者の今後 の研究課題として残されている。

本稿は当日書記を担当された大場茂明氏（大阪市 大）の御尽力によるところが大きい。記して謝意を 表する。

\section{研究部会要旨}

《第22回経済・都市地理研究部会》

1987年11月 8 日（日）人文地理学会大会

於 関西大学

\section{多極分散と 4 全総}

話題提供者 秋山道雄 - 小杉 毅・今野修平

部会では, 四全総の抱える問題点を 3 点にしばっ て報告した。

第 1 は, 四全総が唱える多極分散型国土構造の創 出という政策目標と，これを実現するための手段で ある交流ネットワーク構想の推進とは, 乘離する可 能性をもつことである。現実の経済活動に照らして みると, 全国 1 日交通圈の形成などは地域間の垂直 的分業を一層加速させることによって, 目標に対す る逆効果をもたらす可能性がある。 